solute, equation 2 can be solved for the activity coefficients of the pure solute $\left(\gamma^{x_{1} Y}\right)$ at the innic strengths of the mixed solutions, which are often greater than the saturation strength $I$ of the pure salt $X_{1} Y$. As the activity coefficients so obtained must be independent of the nature of the second solute, agreement of the values of $\gamma^{X_{1} Y}$ obtained from different combinations of solutes provides a very stringent test for the theory.

The accompanying diagram shows the activity coefficients of supersaturated solutions of pure barium nitrate calculated from its solubility data in the presence of barium chloride, potassium, sodium, calcium and ammonium nitrates, and nitric acids, all of which agree perfectly in spite of the greatly differing effect of these solutes on the solubility of barium nitrate. The method is particularly suitable for the calculation of activity coefficients in supersaturated solutions of salts of medium and low solubility, and it promises a considerable extension of our knowledge of activity coefficients by the application of equation (2) to the enormous mass of existing solubility data.

\section{RIVER-FLOW SURVEY AND RECORDS}

A GEOPHYSICAL Discussion on the subject of "River-Flow Survey,and Records" was held by the Royal Astronomial Society in its ronms at Burlington Fouse London, W.1, on January 28, 1949 , with sip A ger Hetherington in the chair. Br. H. of f. Gourley hened the discussion. He said tha rive s have Ginays played a very important poin in lif lite community. In Great Britain the 1.1 and trlburies, which are free of contamination form the chief source of water supply. The larger tributaries and main streams determine the sites of villages and towns and provide the necessary water for industrial development. Thus, quite apart from its scientific interest, an accurate knowledge of river flow is of great importance. The minimum flow is of special significance, for it determines the amount of water available for industrial processes such as cooling, and limits the amount of effluent which may be discharged with. out excessive contam. ination. In areas liable to flooding, the maximum flow is also of obvious importance.

The Land Drainage Act of 1930 made no provision for Govern. ment grants towards the expenses involved in gauging the flow in British rivers, but the River Boards Act (1947) has now rem. edied this. It also empowers the Ministry of Health to make recommendations to the various river boards. At present, the Thames is the only river in Great Britain for which day to-day records exist. In other cases, the Meteorological Office the presence of other solutes. Inset : solubility product of $\mathrm{Ba}\left(\mathrm{NO}_{3}\right)_{3}$ in mixed solntions provides good estimates of the rainfall, but lack
of knowledge of evaporation and storage makes estimates of run-off somewhat uncertain. They form the principal data from which the engineer can work, and provide a valuable means of obtaining advance information of floods. Nevertheless, they cannot replace accurate gauging, and it is to be hoped that the Ministry of Health will, in future, give every encouragement to this type of work.

Dr. J. Glasspoole, of the Meteorological Office, described how estimates of river flow can be made from rainfall data. Great Britain is remarkably well equipped with rain gauges, and analysis of the records from these has led to a good understanding of the effect of topography on the distribution of rainfall. The actual precipitation over a given basin can usually be determined to within a few per cent. but to derive the run-off in the river requires, in addition, a knowledge of storage and evaporation. Neither is accurately known, but, even so, the correlation coefficient between rainfall and run-off is 0.9 , indicating that 80 per cent of the observed

\footnotetext{
'Guggenheim, E. A., Phil. Mag.,19, 606 (1935) (equation 52, symbols changed).

" Harned, H. S., and Owen, B. B., "Physical Chemistry of Electrolytic Solutions", table 11-4-1A, p. 547 (1943).

${ }^{3}$ Robinson, R. A., and Stokes, R. H., Trans. Farad. Soc., 36, 735 (1940).

${ }^{4}$ Harned, H. S., and Geary, C. G., J. Amer. Chem. Soc., 59, 2032 (1937)

s Solubility data from Gmelin's "Handbook" (8th edit.).

- Brönsted, T., J. Amer. Chem. Soc., 44, 877 (1922).
} 
fluctuations in river flow can be accounted for by precipitation. To obtain better results there must be close collaboration between meteorology and hydro. logy. Further information is required on snowfall and its rate of melting. The factors affecting evaporation are very complex, and although considerable work has been done on this problem, it seems unlikely that reliable estimates can be made at present. River flow records are therefore an essential factor, not only for determining the actual run-off but also as a means of finding out about storage and evaporation.

The technical problems involved in gauging the flow of a river were described by Capt. W. N. McClean. When measurements are required, it is seldom practical to construct a special weir or flume, and in these circumstances the best method is to select a stable reach and measure the flow through this with a current meter. Readings must be taken over the whole cross-section area and integrated to give the total flow. Means of locating the current meter quickly and accurately are of great practical im. portance, and some details were given of a suitable cableway which could be stretched across the river and from which the meter could be lowered at any selected point to the required depth. Measurements of flow have been made for several rivers in Scotland, and fifteen years of continuous records for five of these have been published in tabular form by Capt. McClean. But much more work is required. Water is a very valuable asset, more valuable even than coal, and yet there is no Inland Water Survey in Great Britain. Recent flood damage on the main railway line north of Berwick might well have been averted had there been adequate rainfall and run-off data available to the engineers who designed the line. The silting up of estuaries and the design of hydroelectric schemes are also problems for which river flow records are essential. There is a great need for an organised survey, calling for close co-operation between the Ministry of Health, the Ordnance Survey, the Meteorological Office, the Ministry of Agriculture and Fisheries, and the various river boards and water supply authorities.

Mr. W. Allard, of the Ministry of Health, explained how it is that in the past so little attention has been given in Great Britain to river flow recording. Water supplies are abundant, and there has been no difficulty in meeting the small requirements. In the case of the Thames, very complete data exist; records of the flow at Teddington weir go back as far as 1883. In due course, no doubt, the various river boards will put forward their own suggestions for surveys. Both graphical and tabular methods of recording river flow were considered by Mr. Allard, and it was shown how such data could be used to predict floods and to estimate the changes in flow which would result from a given precipitation.

A lively discussion followed in which all agreed that a more complete survey of river flow is most desirable. Mr. E. Gold pointed out that the average flow gave little useful information and that it was important to know the fluctuations. The Zambesi Falls were given as an example. Here the average annual ratio of maximum to minimum run-off is about 30 to 1 , which makes the falls almost useless as a source of hydro-electric power. There were, however, considerable differences of opinion as to the best method of making the measurements. Mr. R. V. Stock, of the Thames Conservancy, described the system of weirs in use at Teddington and explained how it was intended to extend and improve them, to obtain greater accuracy especially at times of minimum flow. Sir Claud Inglis stated that weirs and throated flumes gave the best accuracy, but Capt. McClean maintained that the propeller type of current meter could give excellent results, and, further, could be used on any stable reach of a river without the need for special constructional work. Mr. J. F. Francis, however, doubted if the latter could provide measurements accurate to better than a few per cent; for very low rates of flow, propeller gauges are not reliable.

\section{$\left.\longrightarrow \quad 30\right|_{3}$ \\ COMMONWEALTH COUNCIL FOR SCIENTIFIC AND INDUSTRIAL RESEARCH}

7 HE twenty-first annual report of the Couneil for Scientific an Industrial Research*, Commonwealth of Au thlia, covering the year ended June 30, 1947, states mat consideration was being given to the esfalinif ent of two divisions for textile research, one f(r) fund mental work on the chemistry and A r sic of the wool fibre, and the other to concentrate da the technology of the spinning and utilization of wod. It was hoped at an early stage to commence some work on the degreasing of wool with hydrocarbon solvents as distinct from the normal soap and water scours, and that university research workers will be encouraged to study the fundamental structure and properties of the wool fibre. Other new develop. ments include the appointment of an officer to take charge of the Meteorological Physics Section, where work for a few years will centre on the detailed examination of the atmospheric conditions over a small area. Arrangements have also been made by the Council for a small co-operative section of metal. lurgy to be accommodated at the University of Melbourne. The initial programme of work will include studies of the properties of metals at high temperatures, the preparation of metal compacts from metal powders and the application of $\mathrm{X}$-rays to studies of metals and alloys. A small team of engineers and chemists has been collected to study the utilization of atomic energy for industrial purposes; this team will work at Harwell, England, and arrangements have also been made for a cooperative programme of research in nuclear physics at the University of Melbourne. A Tracer Element Research Committee has been appointed to advise the Council in work with radioactive isotopes.

Reports have indicated that much of the trouble existing in Australian coal mines could be alleviated by applying established methods of dust prevention, and it has also been recommended that a more detailed survey should be made of the conditions in the mines and into the best means of measuring dust concentrations; and as a result of the visit of the late Prof. T. David Jones, the Council has established a Coal Dust Research Advisory Com. mittee to advise on a programme of research. Attention was also given to the scientific aspects of plans for the Australian Expedition to the Antarctic during 1947-48. The Expedition was expected to pay particular attention to geophysical problems, including meteorology, the earth's mag.

* Commonwealth of Australia. Twenty-first Annual Report of the Council for Scientifle and Industrial Research for the year ended 30th June, 1947. Pp. 139. (Canberra : Commonwealth Government Printer, 1948.) 68. 